J. Amer. Soc. Hort. Sci. 116(5):835-837. 1991.

\title{
Primary Bud Hardiness of Four Genotypes of Grapes in Arkansas
}

\author{
Timothy F. Bourne'and J.N. Moore ${ }^{z}$ \\ Department of Horticulture and Forestry, University of Arkansas, Fayetteville, AR 72701 \\ Milon F. George ${ }^{3}$ \\ Department of Forestry, Fisheries, and Wildlife, University of Missouri, Columbia, MO 65211 \\ - Additional index words. cold hardiness, supercooling, differential thermal analysis, Vitis
}

\begin{abstract}
Four interspecific grape hybrids (Vitis spp.) developed in Arkansas were evaluated for primary bud hardiness by differential thermal analysis. Buds from two locations were analyzed over 2 years for acclimation, midwinter hardiness, and deacclimation. In addition, effects of two training systems on cold hardiness of buds were evaluated in one location. The buds of the two genotypes with the greatest component of $\mathrm{V}$. vinifera in their ancestry acclimated more slowly than did the other genotypes. Ultimate midwinter bud hardiness was greater in the genotypes possessing less V. vinifera than other parentage. No effect on cold hardiness due to training system was noted. No natural winter freeze damage was observed on any of the genotypes in the period of observation.
\end{abstract}

New grape cultivars should combine consumer acceptability and climatic adaptation. Insufficient cold hardiness is often a major limitation of grape cultivars in the eastern United States. Genetic improvement of cold hardiness in plants is difficult because of the complexity of hardiness. Stushnoff (1972) outlined some of these problems in relation to breeding for cold hardiness in deciduous fruit crops. Complicating factors of coldhardiness determination include effects of site and season. Plant breeders must choose among several methods of determining cold hardiness. Artificial means of evaluation may reduce selection time, as test winters that disclose differential responses for hardiness occur sporadically.

Survival of some tissues in many woody species depends on supercooling of water in cells of those tissues. The resistance to ice nucleation appears to be at either the tissue (Quamme et al., 1972) or cellular level (George, 1983). Supercooling of water in grape tissues was first described by Pierquet et al. (1977). They noted that exotherms of primary buds in a differential thermal analysis system generally occurred at higher temperatures than did stem tissue exotherms and were larger than associated exotherms of secondary and tertiary buds. This response indicated that primary buds are generally less hardy than stem tissues. Confirmation of this finding came with later work using differential thermal analysis (Andrews et al., 1983) and viability testing (Howell and Shaulis, 1980; Stergios and Howell, 1977; Wolpert and Howell, 1984). Most cold-hardiness analysis of grapes has employed viability testing of large samples over a range of temperatures to produce an estimate of the temperature at which $50 \%$ of a supercooled tissue is killed (Bittenbender and Howell, 1974). However, the use of thermopiles, which allow exotherm detection of numerous tissue samples at once (Andrews et al., 1983), and the demonstration of good agreement between data derived from thermopile use and via-

\footnotetext{
Received for publication 18 Sept. 1990. Published with the approval of the Director, Arkansas Agricultural Experiment Station. We gratefully acknowledge the assistance of Dan Puckett in accessing the DISSPLA plotting program. The cost of publishing this paper was defrayed in part by the payment of page charges. Under postal regulations, this paper therefore must be hereby marked advertisement solely to indicate this fact.

'Former graduate assistant, now Assistant Professor, Center for Viticultural Sciences, Florida A\&M Univ., Tallahassee, FL 32303.

${ }^{2}$ Distinguished Professor.

${ }^{3}$ Professor.
}

bility testing have allowed screening of more samples in less time (Wolf and Pool, 1987).

The major purpose of our study was to characterize primary bud hardiness in 'Saturn', a new grape cultivar released from the Univ. of Arkansas grape breeding program, in relation to other cultivars and lines at several dates. A second objective was to determine primary bud hardiness of the genotypes as affected by training system.

\section{Materials and Methods}

Four interspecific Vitis hybrids were tested for cold hardiness. These included 'Venus' (Moore and Brown, 1977) and 'Mars' (Moore, 1985), known intermediate and hardy types in Arkansas, respectively, and two less well-characterized genotypes, 'Saturn' (Moore et al., 1989) and the advanced selection A1335. Plant materials were collected from replicated plantings at the Main Experiment Station at Fayetteville, Ark., and the Fruit Substation, Clarksville, Ark. Plantings at both locations were in randomized complete blocks with four replications at Clarksville and three at Fayetteville. A replication consisted of a three-vine plot of clonally propagated vines trained to the fourarm Kniffin training system (Ahmedullah and Himelrick, 1990). In the 2nd year of the study, a second group of vines trained to the bilateral cordon system (Ahmedullah and Himelrick, 1990) was added to the study at Fayetteville. Vines at Clarksville were planted in 1985 and fruited for the first time in 1987. Vines at Fayetteville were planted in 1986 and first fruited in 1988.

Four two-bud stem sections were collected from each vine at each sampling date in 1987-88. In 1988-89, only two stem sections were harvested from each vine at a sampling date. Samples were taken from well-exposed canes starting with nodes 15 and 16 on the first sampling date. Upon collection, samples were immediately placed in plastic bags, placed on ice for transport, and kept at 0C until testing. Because of the many genotype/replication combinations, freezing of samples collected at a particular date took place over $\approx 1$ week. Freezing studies were done on the more basal of the two buds to avoid desiccation effects between sampling dates. Within a replication, buds were tested simultaneously. Buds were excised from stems leaving $\approx 1$ to $2 \mathrm{~mm}$ of woody stem tissue. Buds were placed on $3 \times 3 \mathrm{~cm}$ thermopiles (Melcor Electronics, Trenton, N. J.) on which a piece of moistened paper towel had been placed to serve as a heterogeneous nucleator. The water in the towel froze 
over a range of temperatures from about -3 to -6 C. A $0.5105-$ $\mathrm{mm}$ diameter copper-constantan thermocouple was placed on the opposite side of the thermopile, and parafilm was used to keep the buds and thermocouple in constant contact with the plate. Two layers of aluminum foil were wrapped outside of the parafilm to maintain good heat exchange between the two sides of the plate. Thermopiles were placed inside small glass jars that were placed in a programmable freezing chamber (Tenney Jr., Tenney Inc., Union, N.J.). Six thermopiles were used in the system. Chamber setpoint was controlled with a data acquisition system (Interactive Microware, State College, Pa.) interfaced with a microcomputer. All freezing experiments were initiated at $0 \mathrm{C}$ at a cooling rate of $3 \mathrm{C} / \mathrm{h}$. Since several buds (six to 12) were. placed on each plate, the largest low-temperature exotherms corresponding to a number not exceeding the number of buds were noted. Mean exotherm temperatures were derived for each three-vine replication and data were subjected to an analysis of variance (ANOVA) with genotypes as whole plots and dates as subplots in a split-plot analysis.

\section{Results and Discussion}

At both locations in both years there were highly significant effects $(P \leq 0.01)$ due to genotype, date, and genotype $\times$ date interactions in ANOVA (not shown). Effects of training systems and genotype $x$ training system interactions at Fayetteville in 1988-89 were not significant.

At Clarksville in 1987-88, 'Mars' and A-1335 acclimated to a higher degree early in fall than did 'Saturn' and 'Venus' (Fig. 1). Levels of hardiness were greater for 'Mars' and A-1335 than for 'Saturn' and 'Venus' for most of the winter. All genotypes had attained levels of hardiness in early December that were not significantly exceeded as vines were subjected to lower temperatures in January and February. 'Saturn' and A-1335 showed no significant loss in hardiness up to 11 Feb., though both 'Mars' and 'Venus' were significantly less hardy in January and February than in December.

At Fayetteville, 'Venus' was no less hardy on 20 Oct. than 'Mars' or A-1335, but was significantly less hardy than 'Mars' or A-1335 at the 3 Dec.-11 Feb. collection dates, as was 'Saturn' (Fig. 2). Genotypes did not differ in hardiness at the 27 Feb.-29 May collection dates except 'Venus' and 'Saturn' were less hardy than the others on 27 Feb. Differences among the collection dates within genotypes were similar to those at

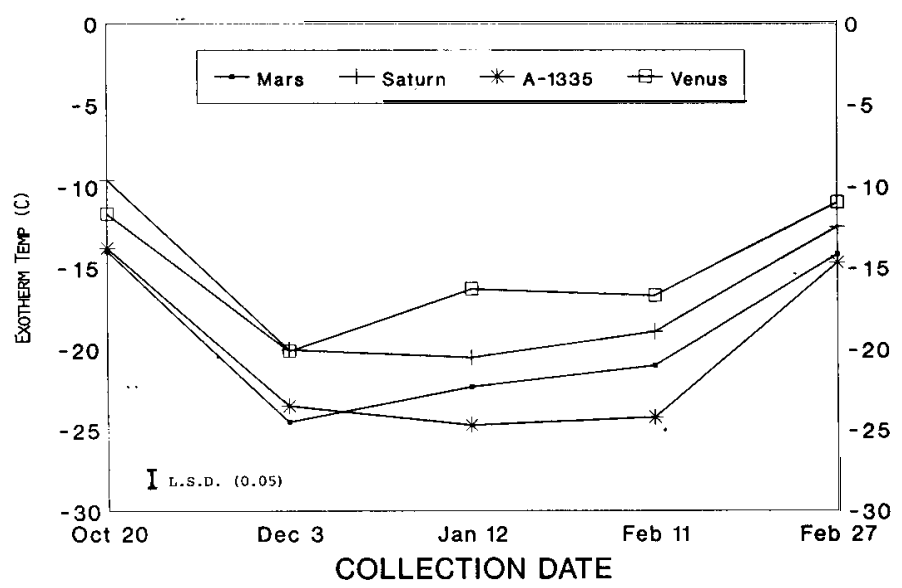

Fig. 1. Exotherm temperatures of buds of four genotypes of grapes, Clarksville, Ark., 1987-88. The vertical bar represents the LSD $(P=0.05)$ among genotypes.

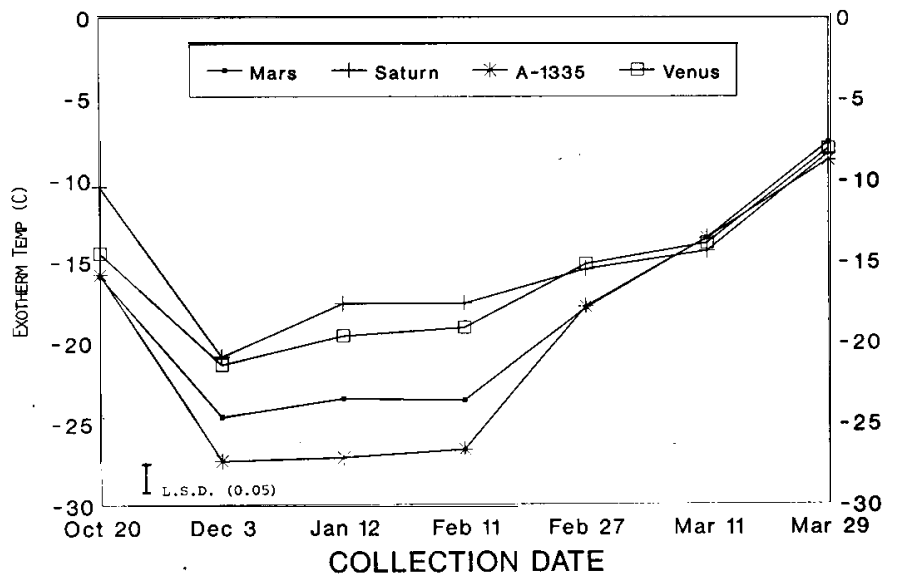

Fig. 2. Exotherm temperatures of buds of four genotypes of grapes, Fayetteville, Ark., 1987-88. The vertical bar represents the LSD $(P=0.05)$ among genotypes.

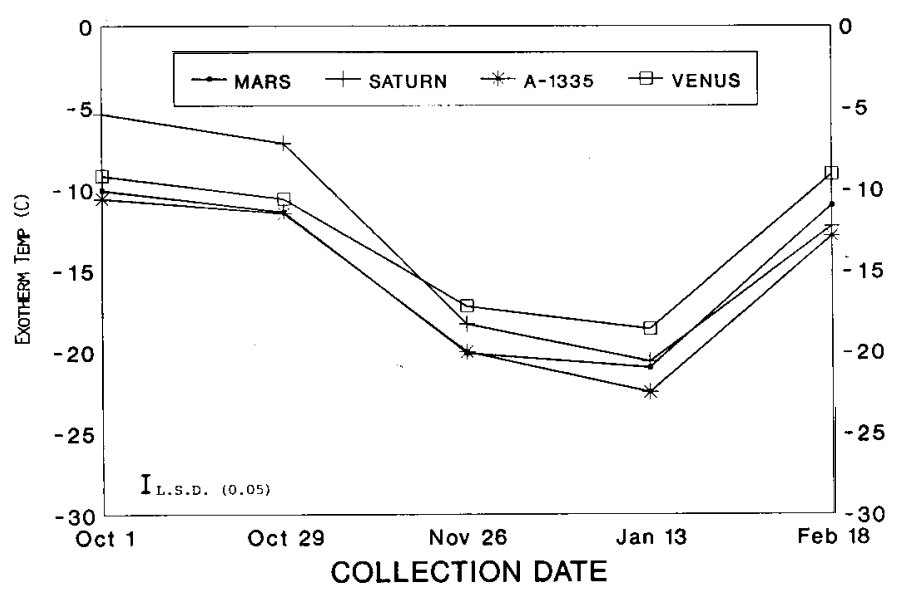

Fig. 3. Exotherm temperatures of buds of four genotypes of grapes, Clarksville, Ark., 1988-89. The vertical bar represents the LSD $(P=0.05)$ among genotypes.

Clarksville, although all genotypes attained a greater degree of hardiness at Fayetteville than at Clarksville.

Sampling in 1988-89 at Clarksville was started earlier and done with greater frequency than in the first year to elucidate the acclimation patterns of the cultivars. 'Saturn' buds produced few low-temperature exotherms at the 1 Oct. collection date, and those produced were at higher temperatures than those of the other genotypes (Fig. 3). No genotype exhibited an average exotherm lower than $-11 \mathrm{C}$ until 26 Nov., when the superior hardiness of 'Mars' and A-1335 was evident. By the 13 Jan. collection date, 'Saturn' had achieved a hardiness level similar to that of 'Mars'. By 18 Feb., all genotypes were reacclimating, and 'Saturn' and A-1335 were not significantly different in hardiness. 'Venus', however, was significantly less hardy than the other three genotypes. The highest levels of hardiness were not achieved before the first freezing temperatures were recorded at Clarksville on 17 Nov. Hardiness levels achieved in November were not significantly exceeded on the January collection date in 'Mars' or 'Saturn', although A-1335 showed increased hardiness in January.

Analysis of the 1988-89 data from Fayetteville again revealed the superior hardiness of A-1335 and 'Mars' (Fig. 4). 'Mars' and A-1335 were similar in hardiness except on the 27 Jan. collection date. 'Saturn', although consistently less hardy than 


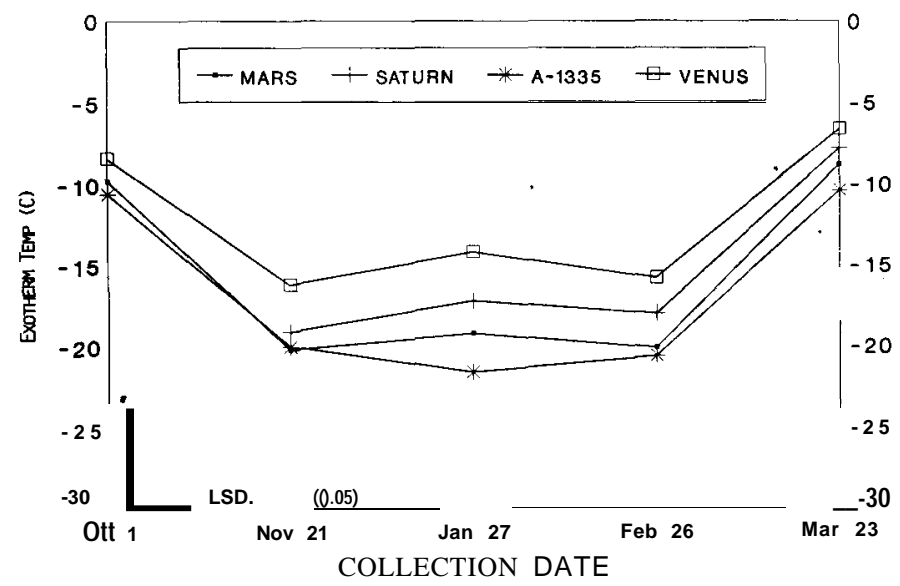

Fig. 4. Exotherm temperatures of buds of four genotypes of grapes, Fayetteville, Ark., 1988-89. The vertical bar represents the LSD $(P=0.05)$ among genotypes.

A-1335 or 'Mars', was significantly hardier than 'Venus' on 21 Nov., 27 Jan., and 26 Feb. 'Saturn', as at Clarksville, did not show early acclimation, and no low-temperature exotherms were produced at the 1 Oct. collection date. 'Mars' and A-1335 maintained a high degree of hardiness from the 21 Nov.-26 Feb. collection dates. 'Venus' and 'Saturn' showed significant loss of hardiness from 21 Nov. to 27 Jan., though by 26 Feb., 'Venus' had increased in hardiness.

The patterns of grape bud exotherm temperature decrease support the hypothesis of Howell and Weiser (1970) that acclimation is a two-stage process in some woody plants. Early season hardiness at Clarksville in 1988-89, before cold weather, was not great in any of the genotypes. After the first frost, however, hardiness increased greatly in all four genotypes. The concept of a minimum hardiness level, first established in peaches (Proebsting, 1963) and later in grapes (Proebsting et al., 1980), seems to be supported by these data as well. After the first freezing temperatures of autumn, the buds of these grapes appeared to establish a hardiness level that was not lost until the dormant period was finished. Sampling was not done often enough to closely follow air temperature effects on hardiness levels. However, all genotypes showed fluctuations in midwinter hardiness levels that have been observed in both $\mathrm{V}$. vinifera and V. labrusca grapes (Andrews et al., 1983; Proebsting et al., 1980; Schnable and Wample, 1987).

'Saturn' has several characteristics of $V$. vinifera grapes, including leaf shape, upright cane growth, absence of a strong labrusca flavor, and a tendency to continue to grow late in summer. 'Saturn', however, has American grape species in its background. The cultivars used are complex interspecific hybrids of $V$. vinifera and $V$. labrusca. The selection A-1335 is a seedling of 'Concord' $\times$ op. A pedigree analysis of these four grapes revealed that the two hardier genotypes possessed a smaller $V$. vinifera parentage than did the more winter-tender types (assuming that 'Concord' is pure $V$. labrusca): A-1335 $=0 \%$, 'Mars' $=40 \%$, 'Venus' $=60 \%$, 'Saturn' $=78 \%$. Certainly, relatively cold-hardy $V$. vinifera genotypes exist, although the early season hardiness needed for continental climates may not be found in most $V$. vinifera cultivars. Although the hardiness of 'Saturn' often does not reach that of 'Mars' or A-1335, it can attain a high degree of bud hardiness. The lowest temper- ature recorded during this study was $-25 \mathrm{C}$ on 8 Jan. 1988, which all genotypes survived with no apparent bud or cane damage. Screening seedling populations or advanced selections using laboratory freezing tests seems to be a viable option for breeding programs. Arkansas conditions do not allow for regular test winter screenings, so characterization of cold hardiness has required long periods of field observations. In this study, there was good agreement between laboratory tests of cold hardiness and long-term observations of winter survival in the field (Moore, 1985; Moore and Brown, 1977; Moore et al., 1989). By using a controlled-temperature cold chamber with a system of thermopiles and thermocouples, many selections may be evaluated quickly and accurately for cold hardiness.

\section{Literature Cited}

Ahmedullah, M. and D.G. Himelrick. 1990. Grape management, p. 383-471. In: G.J. Galletta and D.J. Himelrick (eds.). Small fruit crop management. Prentice Hall, Englewood Cliffs, N.J.

Andrews, P. K., E.L. Proebsting, and G.S. Campbell. 1983. An exotherrn sensor for measuring the cold hardiness of deep-supercooled flower buds by differential thermal analysis. HortScience 18:77-78.

Bittenbender, H.C. and G.S. Howell. 1974. Adaptation of the Spearman-Karber method for estimating the T50 of cold stressed flower buds. J. Amer. Soc. Hort. Sci. 99:187-190.

George, M.F. 1983. Freezing avoidance by deep supercooling in woody plant xylem: preliminary data on the importance of cell wall porosity, P. 84-95. In: D.D. Randall, D.G. Blevins, R,L. Larson, and B.J. Rapp (eds.). Current topics in plant biochemistry and physiology, vol. 2. Univ. of Missouri-Columbia Press, Columbia, Mo.

Howell, G.S. and N. Shaulis. 1980. Factors influencing within-vine variation in the cold resistance of cane and primary bud tissues. Amer. J. Enol. Viticult. 31:158-161.

Howell, G.S. and C.J. Weiser. 1970. Environmental control of cold acclimation in apple. Plant Physiol. 45:390-394.

Moore, J.N. 1985, 'Mars' seedless grape. HortScience 20:313.

Moore, J.N. and E. Brown. 1977. 'Venus' grape. HortScience 12:585.

Moore, J. N., J.R. Clark, and J.R. Morris. 1989. 'Saturn' seedless grape. HortScience 24:861-862.

Pierquet, P., C. Stushnoff, and M.J. Burke. 1977. Low temperature exotherms in stem and bud tissues of Vitis riparia Michx. J. Amer. Soc. Hort. Sci. 102:54-55.

Proebsting, E.L. 1963. The role of air temperature and bud development in determining hardiness of dormant 'Elberta' peach buds. Proc. Amer. Soc. Hort. Sci. 83:259-269.

Proebsting, E. L., M. Ahmedullah, and V.P. Brummund. 1980. Seasonal changes in low temperature resistance of grape buds. Amer. J. Enol. Viticult. 31:329-336.

Quamme, H.A., C. Stushnoff, and C.J. Weiser. 1972. The relationship of exotherms to cold injury in apple stem tissues. J. Amer. Soc. Hort. Sci. 97:608-613.

Schnabel, B.J. and R.L. Wample. 1987. Dormancy and cold hardiness in Vitis vinifera L. cv. White Riesling as influenced by photoperiod and temperature. Amer. J. Enol. Viticult. 38:265-272.

Stergios, B.G. and G.S. Howell. 1977. Effects of defoliation, trellis height, and cropping stress on the cold hardiness of Concord grapevines. Amer. J. Enol. Viticult. 28:34-42.

Stushnoff, C. 1972. Breeding and selection methods for cold hardiness in deciduous fruit crops. HortScience 7:10-13.

Wolf, T.K. and R.M. Pool. 1987. Factors affecting exotherm detection in differential thermal analysis of grapevine dormant buds. J. Amer. Soc. Hort. Sci. 112:520-525.

Wolpert, J.A. and G.S. Howell. 1984. Effects of cane length and dormant season pruning date on cold hardiness and water content of Concord bud and cane tissues. Amer. J. Enol. Viticult. 35:237-241. 